\title{
INVESTIGATION OF HEAVY-MINERAL DEPOSITS USING MULTISPECTRAL SATELLITE IMAGERY IN THE EASTERN COASTAL MARGIN OF BANGLADESH
}

\author{
1 Department of Geology, University of Dhaka, Dhaka-1000 \\ 2Department of Oceanography, University of Dhaka, Dhaka-1000 \\ *Corresponding Author Email: yousuf.geo@du.ac.bd
}

Md. Yousuf Gazi'*, Khandakar Tahmida Tafhim², Md. Kawser Ahmed², Md Atikul Islam²

This is an open access article distributed under the Creative Commons Attribution License, which permits unrestricted use, distribution, and reproduction in any medium, provided the original work is properly cited.

\section{ARTICLE DETAILS}

Article History:

Received 26 August 2019 Accepted 29 September 2019 Available online 18 October 2019

\section{ABSTRACT}

Sea beaches are always a good source of heavy minerals around the world. Cox's Bazar has $120 \mathrm{~km}$ of unbroken sandy sea beach. The study includes the sea beaches of 5 upazilas (Moheshkhali, Kolatoli, Ramu, Ukhia, Teknaf) in Cox's bazaar district for studying the concentration, identification and investigation of heavy mineral deposits along the sandy beaches. This study has concentrated on the physical properties, identification, and abundance of the heavy minerals fraction in sediments collected from the study area. Satellite imagery Landsat-8 OLI was used for remote sensing verifications. The image processing and crucial analysis carried out using Environment for Visualizing Images (ENVI), Arc GIS and Erdas Imagine software. Coastal areas adjacent to Teknaf upazila has a very significant amount of heavy mineral reserves, almost 16\%. The study has identified around nineteen variety of heavy minerals from the collected samples in the study area. Ilmenite, Kyanite, Garnet, Rutile, Zircon, Magnetite, Augite, Hornblende, Enstatite, Epidote, Andalusite, Hypersthene, Diopside and Cassiterite have been found the most abundant in the entire study area. The Coastline of Bangladesh was surveyed completely to map the heavy minerals which are potential resources for our national economy.

\section{KEYWORDS}

Mineral Deposits, Heavy-Minerals, Satellite Imagery, Easterns Coastal Margin, Bangladesh.

\begin{abstract}
1. INTRODUCTION
Heavy mineral sands generally contain high specific gravity $(\mathrm{SG}>2.9)$ and occurring as detrital minerals such as rutile, sillimanite, monazite, xenotime, chromite, tourmaline, garnet, staurolite, zircon, ilmenite, magnetite, and kyanite. These heavy minerals are resistant to abrasion, chemically stable, and can endure diagenetic modification [1]. Most commonly referring to dense components [2]. Minerals are considered as non-renewable resource which can be taken out by several mining techniques [3]. Utilizations of heavy minerals in the industrial and geological purposes play an important role in the economy of a country $[4,5]$. Developing countries like Bangladesh need to focus on the detail mapping and rigorous exploration activities in the coastal areas of the country. In the coastal areas of Bangladesh, heavy minerals with beach placer deposits are abundant specially in the southern and eastern margin of the coastal belt [6-9].
\end{abstract}

Beach placer deposits generally comprise up to 23\% (by weight) heavy minerals that is much higher than the low-grade river concentrated (1$2 \%$ ) heavy minerals $[10,11]$. The concentration of heavy minerals in terrigenous sediments may vary significantly due to several factors together with provenance, sedimentary processes and post-depositional dissolution $[12,13]$.

A sufficient mineral deposit formed by mechanical concentration of mineral particles from weathered debris. Beach placer and alluvial placer are the two main types of placer minerals [3]. Beach placers are formed when the mechanical or chemical weathering of rock masses and their redistribution along a continental shelf [14]. The sediments are sorted by gradual movement of the sea water, directing the coarser materials towards the shore and the finer materials into deep water [15]. The heavy minerals are gradually resistant to weathering and hence become concentrated. Long time upward movement of the coastal areas, change in sea level and the migration of sands dune blown by the wind over long distance has converted some of these sediments to land and consequently many beach placers occurs a considerable distance inland from the present coast line $[16,17]$. Several authors in Bangladesh outlined the heavy minerals properties, radioactivity, prospect and identification from different parts of the country, specially in the southern part (Coastal area) and northern part (River basin) of the country [18-24].

The beach in Cox Bazar is sandy and has a gentle slope; with an unbroken length of $120 \mathrm{~km}(75 \mathrm{mi})$, it is the longest natural sea beach in the world [25]. The heavy mineral deposits along the coastal belt of Bangladesh contain potential resources. The fore dune deposits areas also contain noticeable amount of heavy minerals, which are being accumulated within the intertidal zone. This part is very dynamic and exposed subject to wave, current and wind actions. Mineral sands on those deposits contain some important metallic minerals mainly ilmenite, magnetite, rutile, zircon, garnet, monazite, kyanite and leucoxene. The heavy mineral concentration along the recent fore dune deposit of Bangladesh ranges from $13 \%$ to $70 \%$, which is quite significant [26]. Development in remote sensing or satellite image and GIS lead to identifying and locating the heavy mineral resources and also essential for proper mapping of mineral resources. Nowadays, remotely sensed data are frequently used for mineral exploration around the world [27-30]. This study will open up new areas for inland heavy mineral exploitation and leads to eco-friendly exploitation of natural resources along the study area. The study utilized the high potential of multispectral satellite data for exploration and mapping of mineral resources in the study area. These heavy minerals can be used in different industries, nuclear power plants, meters and scientific apparatus, welding, rod coating and others. These minerals can be commercially extracted and produced to increase the national income.

\section{STUDY AREA}

The Cox's Bazar coastal areas is situated at the south eastern belt of Bengal basin. It is bordered on the west by the Bay of Bengal, on the north by the Bakkhali estuary and Maheshkhali channel, on the east by low elevated hill ranges $(\sim 100 \mathrm{~m})$, and on the south by the headlands (Figure 1). The beach 
area is totally exposed to the long shore current and episodic tidal oscillations. The beach area can be subdivided into: dunes, tidal creeks and beach. The width of the main beach plain is $200-300 \mathrm{~m}$ at the mean sea level [31].

The study includes the sea beaches of Moheshkhali, Kolatoli, Ramu, Ukhia, Teknaf upazila in Cox's bazaar district. Samples were collected from these 5 upazilas for the identification and investigation of heavy mineral deposits along the sandy beaches of the study area. During fieldwork conducted on the beach area, surface and subsurface samples were collected extending from the surface to $\sim 1 \mathrm{~m}$ depth (using hand auger). Total 30 samples were taken from 30 different locations: Four from Kolatoli, three from Ramu, eleven from Teknaf; seven ukhia, and five samples from Moheshkhali.

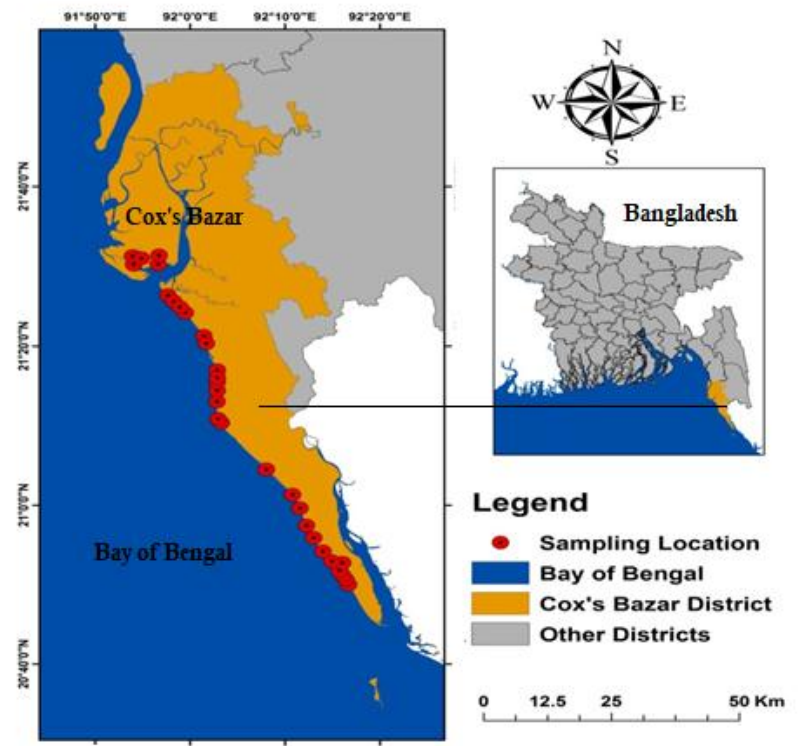

Figure 1: Study area map showing the sample locations

\section{MATERIALS AND METHODS}

The entire study workflow consists of four steps apart from field investigation including sample collection: a) Sieving, b) Heavy and light mineral separation technique, c) Thin section and d) Identification by a petrographic microscope and processing of satellite image for remote sensing verification.

\subsection{Grain size analysis}

Collected samples were dried and run through some physical separation techniques. Grain analysis was employed for the collected samples by using sieving techniques with different US standard mesh $>500 \mu \mathrm{m}$, $250 \mu \mathrm{m}, 125 \mu \mathrm{m}, 63 \mu \mathrm{m}$ and $<63 \mu \mathrm{m}$ was used (Ingram 1971). For this, 50 gm of the dry samples weight were taken and each was carefully recorded the weight of each sieve with its retained samples.

\subsection{Separation of Heavy Minerals}

Gravity separation was employed in this study for heavy mineral separation. The procedure was carried out under a well-ventilated hood; here bromoform was used as a heavy liquid, which has a specific gravity 2.89 at $20^{\circ} \mathrm{C} .50-60 \mathrm{ml}$ bromoform was used for $50 \mathrm{gm}$ raw / previously sieved sand. Another beaker was placed beneath the separating funnel and a filter paper labeled was placed on a glass funnel over the beaker. After pouring the bromoform one of the raw samples were poured and stirred with a glass rod until the heavy and light minerals are separated completely. It was allowed to stand undisturbed for some time so that separate layer of light minerals, bromoform and heavy minerals are formed.

\subsection{Slide preparation for optical study}

Slides were prepared for investigating the optical properties of the heavy minerals in the samples. Canada balsam stick was melted on glass slide on hot plate and heavy mineral grains were dropped into it, removed the slide from hot plate and allowed cement to harden by cooling, cover slip was placed onto the glass slide before the microscopic study. The percentage, amount, concentration of valuable minerals can be identified by three different point counting methods [32]. In this study, Line counting method was used for the determination heavy mineral percentages. Properties of heavy minerals studied and identified under polarizing microscope (Figure 9).

\subsection{Remotely sensed data and techniques}

For this purpose, ENVI 5.1 version with the ArcGIS 10 and Erdas Imagine 9.2 has been used for mapping heavy minerals from satellite imagery. Landsat 8 OLI image dated $18^{\text {th }}$ May, 2017 has been collected from the website https://earthexplorer.usgs.gov. Before identifying the mineral deposits, radiometric correction and fast line-of-sight atmospheric analysis of spectral hypercube (FLAASH) were employed to remove the effect of aerosols, clouds and cloud shadows (Figure 2). The reflectance calibration of the Landsat ETM data was performed with pre-launch gains and offsets calculated for Landsat sensors [33]. After preprocessing, the data is subjected to hourglass spectral analysis. The MNF transformation was applied to the atmospherically corrected and calibrated data and it generates six MNF-transformed bands which can be viewed and analyzed (Figure 3). It mainly reduces the computational requirements for subsequent processing.
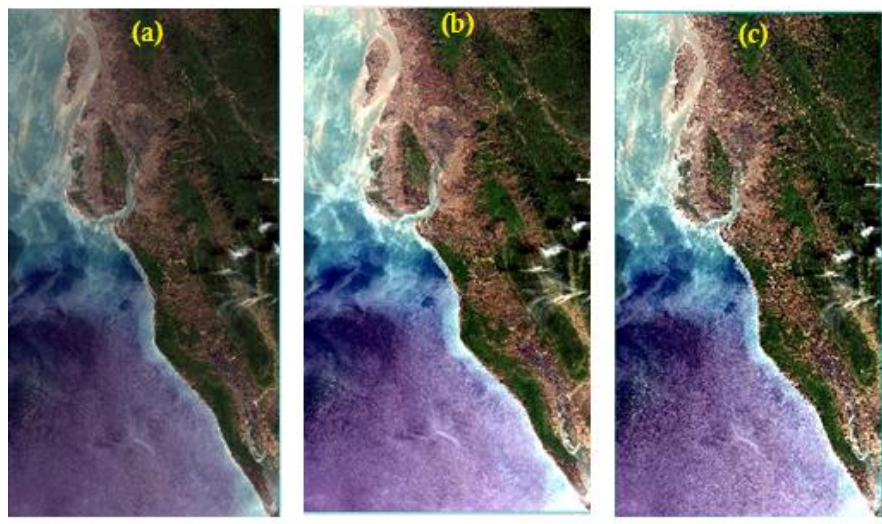

Figure 2: (a) Landsat-8 OLI before image corrections (b) Image after radiometric calibration (c) After atmospheric correction (FLAASH) (a)

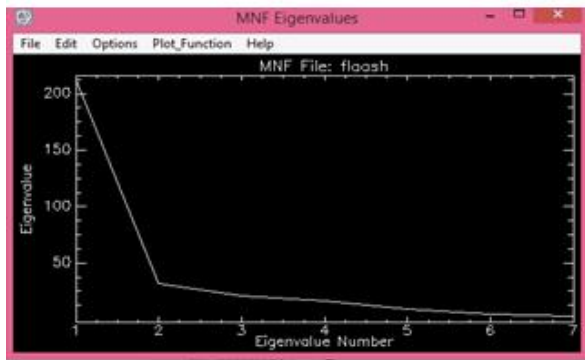

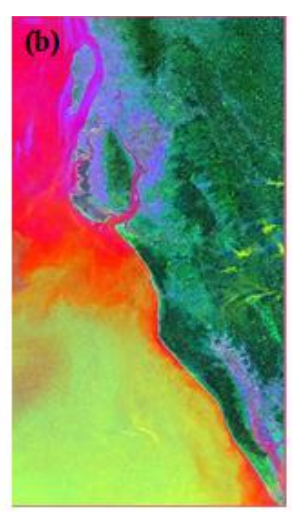

Figure 3: (a) Eigenvalue plot for different MNF bands of ETM data (b) MNF Result display

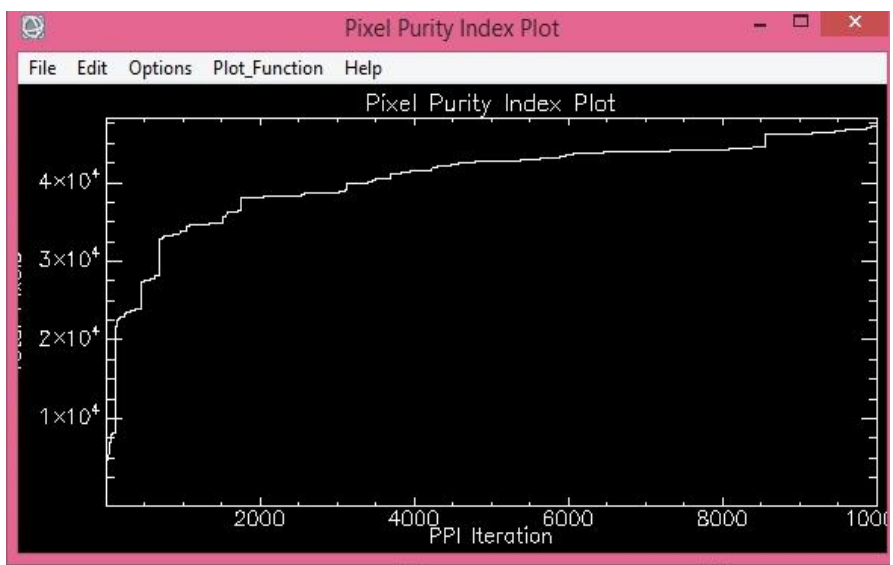

Figure 4: Pixel purity index plot 


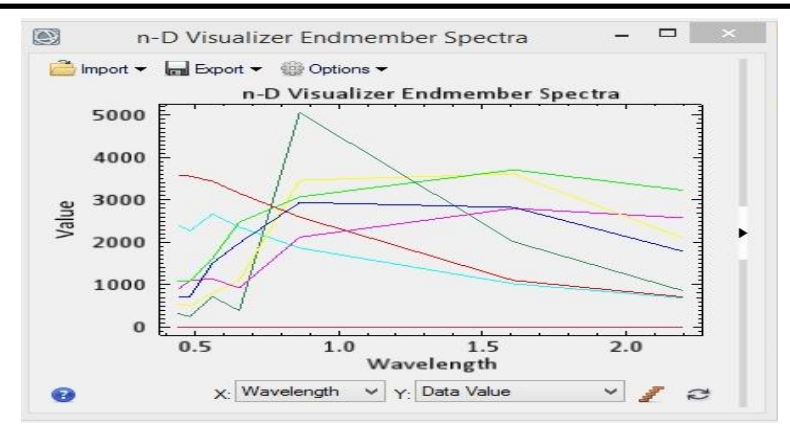

Figure 5: n-D Visualize Endmember Spectral plot.

In this work the PPI analysis was performed on the MNF bands with 10000 iterations and a threshold value of 3. Pixel purity index ENVI's pixel purity index (PPI) is a way of finding the most spectrally pure or extreme pixels in images (Figure 4) [34,35]. ENVI's n-dimensional visualizer used for finding endmembers by locating and clustering the purest pixels in ndimensional space (Figure 5).

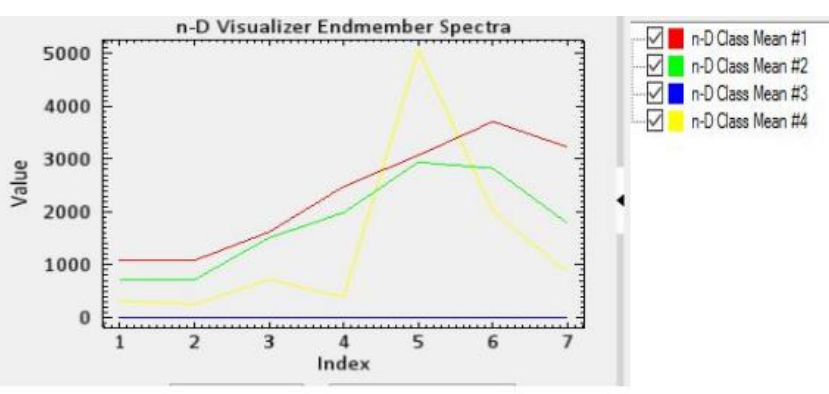

Figure 6: Selected endmembers from the spectral plot.

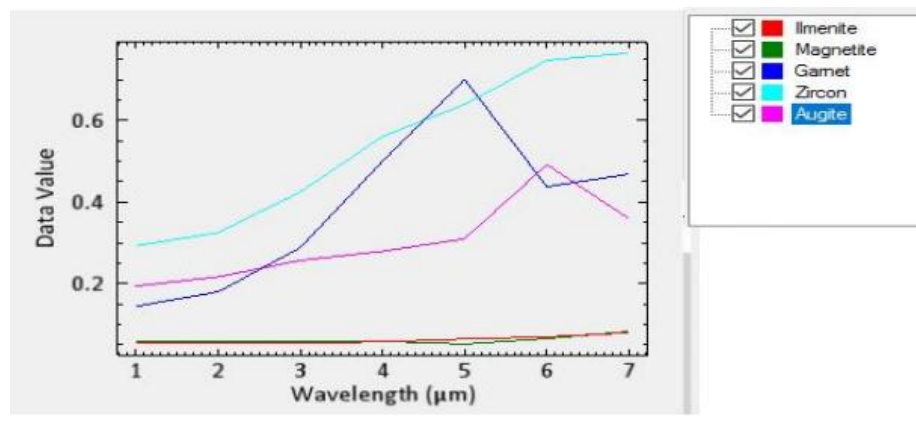

Figure 7: A Spectral plot of minerals obtained from the USGS spectral library.

\subsection{Mapping of Minerals Using Spectral Angle Mapper}

The selected and verified target endmembers present in the data are mapped with ENVI's spectral angle mapper (SAM). SAM is the most-used mapping method for minerals using hyperspectral data [36]. SAM is an automated method for comparing image spectra to individual spectra (Figure 6). By calculating the spectral angle between them, the similarity between two spectra is determined, treating them as vectors in a space with dimensionality which is equal to the number of bands (Figure 7).

\section{RESULTS AND DISCUSSION}

\subsection{Result of Grain Size Analysis}

Grain size distribution pattern identified from Moheshkhali to Teknaf beach area in Cox's bazaar district. The amount of coarse sand and clay particles is higher in Moheshkhali than Kolatoli, Himcchori, Inani and Teknaf. The percentage of medium sand is higher in kolatoli (13.82 $39.78 \%$ ) (Figure 8). The Inani beach contains less medium grained sand $(0.18-8.86 \%)$ than the other regions. Fine and medium sand are comparatively higher in some areas of Teknaf beach, which indicates that these areas may have higher percentage of heavy minerals. From the sampling areas, the weight percentage of heavy mineral varies from 0.6 to $72.62 \%$. The weight of light mineral ranges from 25.79 to $99.72 \%$. Size analysis of the samples also showing that grain size is decreasing from North to South direction. A group researchers also found that the grain size of heavy minerals decreases from north to south and the sediments transported from northern region [37].

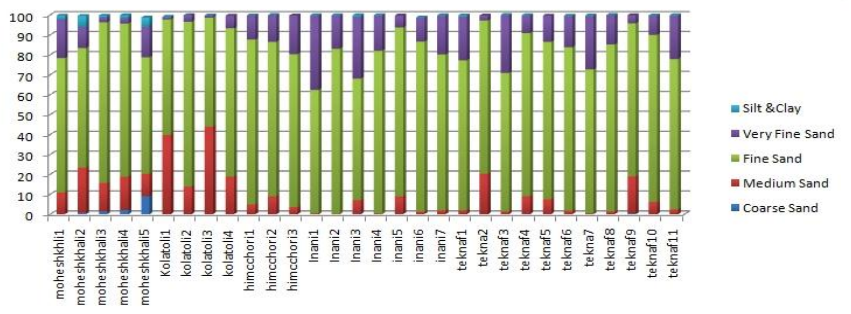

Figure 8: The Overall Grain Size Distribution of the collected samples from sea beaches in Cox's bazar district (Moheshkhali to Teknaf Beach).

\subsection{Heavy Mineral Concentration}

More than 19 types of minerals have found from the study area. Kyanite, Rutile, Zircon, Hornblende, Ilmenite, and Magnetite are very common and identified easily under microscope (Figure-9).

\subsubsection{Kolatoli (Cox's Bazar)}

In kolatoli, the weight percentage of heavy minerals varies between 10.88 and $15.36 \%$ (Table 1 ). kyanite has weight percentage of (0.25-0.48), garnet $(0.1-0.59)$, rutile $(0.12-0.59)$, andalusite $(0.2-0.39)$, augite $(0.37$ 1.17), ilmenite (4.40-5.50), magnetite (0.36-0.72), hornblende (0.20-0.48), enstatite(0.10-0.24), staurolite (0.25-0.39), hypersthene (0-0.39), cassiterite (0.12-0.39), diopside $(0.12-0.25)$, zircon(0.2-0.30), epidote (1.2-3.5) (Table 1).

In kolatoli-1 (Hatchery point), the amount of garnet, Hypersthene and augite are higher than the other areas of kolatoli. The amount of magnetite is higher in kolatoli-4 (Diabetes point). The abundance of ilmenite is more abundant $(\sim 5.50)$ in kolatoli-3 (Laboni point). In area of kolatoli-4, the percentage of magnetite is higher. Comparatively the subsurface sediment of Kolatoli-1 (Hatchery point) contain more heavy minerals than other areas of Kolatoli region. Because there is no disturbance of the sediment due to tourist and other human intervention in kolatoli-1 (Hatchery Point). Laboni point contains fewer heavy minerals than other areas of Kolatoli, Cox's Bazar.

Table 1: The weight percentage (\%) of light \& heavy minerals at kolatoli region

\begin{tabular}{|c|c|c|c|c|c|c|c|c|c|c|c|c|c|c|c|c|c|c|c|}
\hline 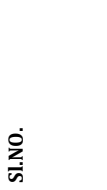 & 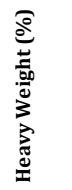 & 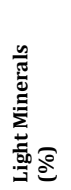 & 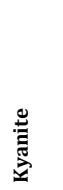 & 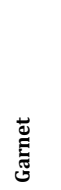 & 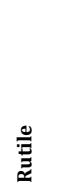 & 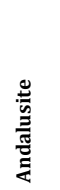 & 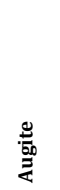 & 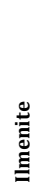 & 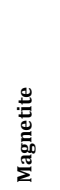 & 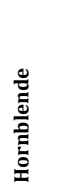 & 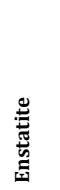 & 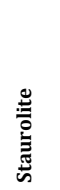 & 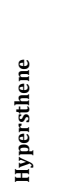 & 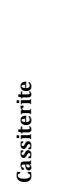 & 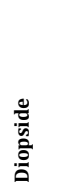 & 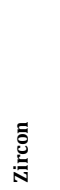 & 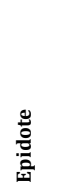 & 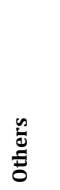 & 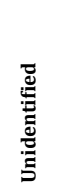 \\
\hline Kolatoli-1 & 15.36 & 84.64 & 0.39 & 0.59 & 0.59 & 0.39 & 1.17 & 4.50 & 0.59 & 0.20 & 0.20 & 0.39 & 0.39 & 0.39 & 0.2 & 0.30 & 3.50 & 1.37 & 0.20 \\
\hline Kolatoli-2 & 12.52 & 87.48 & 0.25 & 0.10 & 0.20 & 0.20 & 0.37 & 5.50 & 0.49 & 0.37 & 0.10 & 0.25 & 0.00 & 0.30 & 0.25 & 0.20 & 2.10 & 0.49 & 1.35 \\
\hline Kolatoli-3 & 10.88 & 89.12 & 0.48 & 0.24 & 0.12 & 0.20 & 0.48 & 5.10 & 0.36 & 0.24 & 0.24 & 0.30 & 0.24 & 0.12 & 0.12 & 0.30 & 1.50 & 0.12 & 0.72 \\
\hline Kolatoli-4 & 2.58 & 7.42 & 0.36 & 0.36 & 0.24 & 0.24 & 0.60 & 4.40 & 0.72 & 0.48 & 0.24 & 0.50 & 0.12 & 4 & 0.24 & 0.24 & 1.20 & 12 & 2.28 \\
\hline
\end{tabular}

\subsubsection{Himchari}

The percentage of heavy mineral varies between (15.61-22.33\%) in different areas of Himchari region (Table 2). In every sampling area in this region, amount of ilmenite, hornblende and Enstatite are higher than other minerals. The percentage of major minerals found in these areas are ilmenite (4.43-6.11\%), hornblende (2.11-3.22\%), Enstatite (1.14-1.23\%). The amount of heavy minerals is comparatively higher in Himcchari-3 (Mangala Para) 


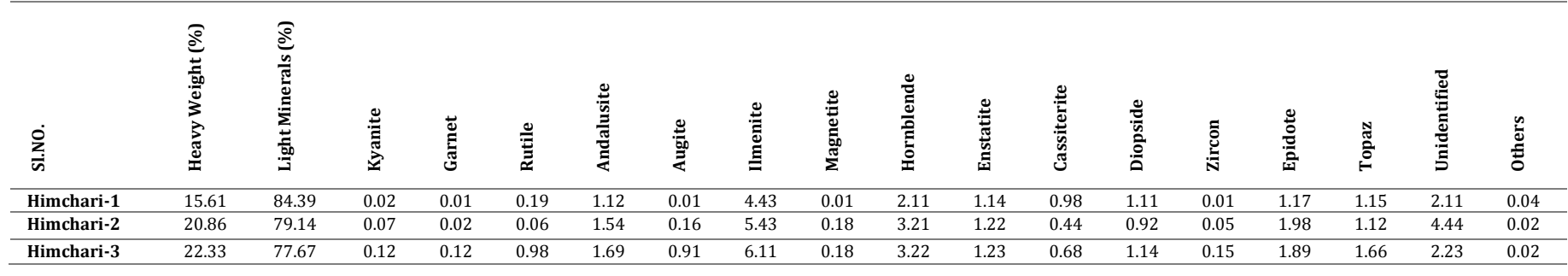

\subsubsection{Inani Beach}

Overall 7 subsurface samples were collected from 7 different areas of Inani beach. Study shows 7 different mineral content patterns. The Inani beach contains (11.35-19.71\%) heavy minerals. The most abundant minerals in these areas are Garnet (0.13-1.22\%), Ilmenite (3.3-5.5\%), Magnetite $(0.11-1.88 \%)$ and Zircon (0.04-1.22\%) (Table 3). In the samples of Inani3 and Inani-5, heavy mineral concentration is higher than other areas of this region.

Table 3: The weight percentage (\%) of light \& heavy minerals at Inani Beach

\begin{tabular}{|c|c|c|c|c|c|c|c|c|c|c|c|c|c|c|c|c|c|c|c|c|}
\hline$\sum_{\dot{\xi}}^{\dot{m}_{j}}$ & 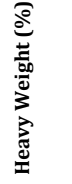 & 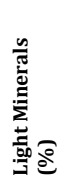 & 愛 & 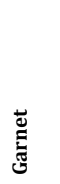 & 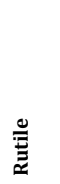 & 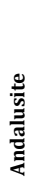 & 哫 & $\begin{array}{l}\stackrel{\mathscr{\Xi}}{\Xi} \\
\text { Ë }\end{array}$ & 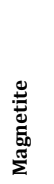 & 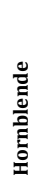 & 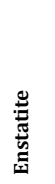 & 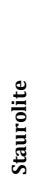 & 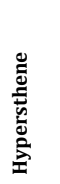 & 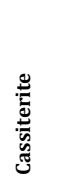 & 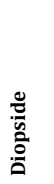 & 节 & 总 & & 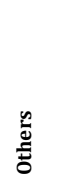 & 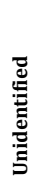 \\
\hline Inani-1 & 16.54 & 83.46 & 0.18 & 0.71 & 0.53 & 1.14 & 0.89 & 4.4 & 0.89 & 0.71 & 2.11 & 0.11 & 0.45 & 0.12 & 0.36 & 0.36 & 1.45 & 0.36 & 0.53 & 1.24 \\
\hline Inani-2 & 18.83 & 81.17 & 0.49 & 1.22 & 0.49 & 1.57 & 0.49 & 4.2 & 1.71 & 0.24 & 2.44 & 0.24 & 0.24 & 0.11 & 0.44 & 1.22 & 1.19 & 0.11 & 0.97 & 1.46 \\
\hline Inani-3 & 19.71 & 80.29 & 0.13 & 0.52 & 0.26 & 1.89 & 0.26 & 5.5 & 0.64 & 0.39 & 3.12 & 0.98 & 0.88 & 0.26 & 0.88 & 0.39 & 2.18 & 0.14 & 0.26 & 1.03 \\
\hline Inani-4 & 18.15 & 81.85 & 0.57 & 1.13 & 0.57 & 0.98 & 0.76 & 3.5 & 0.76 & 0.57 & 2.13 & 0.14 & 0.97 & 0.12 & 0.11 & 0.57 & 1.88 & 0.18 & 0.19 & 3.02 \\
\hline Inani-5 & 19.34 & 80.66 & 0.79 & 1.09 & 0.03 & 2.11 & 0.05 & 5.1 & 1.88 & 0.78 & 3.33 & 1.11 & 0.04 & 0.13 & 0.44 & 0.05 & 2.13 & 0.03 & 0.03 & 0.22 \\
\hline Inani-6 & 12.68 & 87.32 & 0.28 & 0.25 & 0.45 & 1.18 & 0.11 & 3.9 & 0.35 & 0.2 & 1.17 & 0.98 & 0.77 & 0.11 & 0.05 & 0.15 & 1.18 & 0.11 & 0.25 & 1.19 \\
\hline Inani-7 & 11.35 & 88.65 & 0.04 & 0.13 & 0.07 & 0.67 & 0.76 & 3.3 & 0.11 & 0.04 & 1.54 & 0.12 & 0.67 & 0.02 & 0.67 & 0.04 & 2.65 & 0.07 & 0.11 & 0.31 \\
\hline
\end{tabular}

\subsubsection{Teknaf Beach}

Teknaf- 1 and Teknaf- 5 samples contain higher amounts of heavy minerals
(13.29-20.68\%) (Table 4). The major minerals of this regions are Garnet, augite, topaz, ilmenite, magnetite, staurolite, zircon, rutile and epidote.

Table 4: The weight percentage (\%) of light \& heavy minerals at Teknaf Beach

\begin{tabular}{|c|c|c|c|c|c|c|c|c|c|c|c|c|c|c|c|c|c|c|c|c|}
\hline$\sum_{\substack{n \\
\dot{n}}}$ & 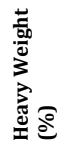 & 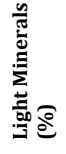 & 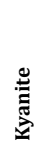 & 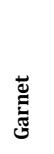 & 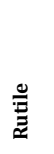 & 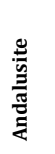 & 总 & 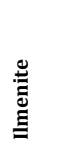 & 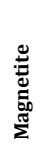 & 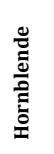 & 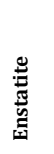 & 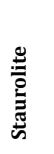 & 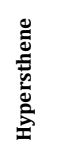 & 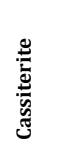 & 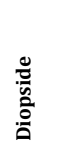 & : & 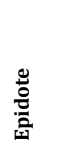 & $\underset{\tilde{J}}{\stackrel{N}{0}}$ & $\begin{array}{l}\stackrel{n}{\tilde{U}} \\
\stackrel{\Xi}{0}\end{array}$ & 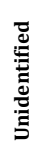 \\
\hline Teknaf-1 & 14.21 & 85.79 & 0.21 & 1.14 & 0.22 & 0.14 & 0.06 & 1.18 & 0.65 & 0.56 & 0.53 & 1.53 & 1.53 & 0.91 & 0.13 & 0.89 & 0.06 & 1.53 & 1.12 & 1.82 \\
\hline Teknaf-2 & 13.86 & 86.14 & 0.58 & 0.87 & 0.87 & 0.21 & 0.87 & 1.74 & 2.61 & 0.58 & 0.29 & 1.09 & 0.34 & 0.12 & 0.45 & 0.32 & 0.35 & 0.14 & 0.98 & 1.45 \\
\hline Teknaf-3 & 3.83 & 86.17 & 0.48 & 0.31 & 0.21 & 0.11 & 0.21 & 3.41 & 0.51 & 0.31 & 0.81 & 1.12 & 0.11 & 0.12 & 0.45 & 0.31 & 0.34 & 0.23 & 3.56 & 1.23 \\
\hline Teknaf-4 & 15.09 & 84.91 & 0.12 & 0.45 & 0.23 & 0.3 & 0.15 & 3.04 & 0.89 & 0.32 & 0.15 & 1.12 & 0.43 & 0.06 & 0.34 & 0.15 & 0.15 & 0.15 & 6.45 & 0.59 \\
\hline Teknaf-5 & 6.72 & 83.28 & 0.34 & 1.38 & 0.38 & 0.45 & 1.07 & 2.07 & 1.07 & 1.69 & 0.32 & 1.69 & 0.34 & 0.09 & 0.69 & 0.11 & 0.13 & 0.38 & 1.83 & 2.69 \\
\hline Teknaf-6 & .57 & 3.43 & 0.32 & 0.32 & 0.87 & 0.56 & 0.32 & 4.32 & 0.32 & 0.32 & 0.11 & 0.11 & 0.21 & 0.11 & 0.21 & 0.43 & 0.21 & 0.32 & 6.54 & 0.97 \\
\hline Teknaf-7 & & & 0.86 & 2.58 & 0.72 & 0.86 & 1.0 & 0.44 & 1. & 1.29 & 0.4 & 0. & 0.86 & 0.4 & & 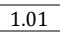 & 0. & 2 & 5 & 5.16 \\
\hline Tekna & & 85. & 0. & 0.9 & 0.8 & 0.2 & 0. & 3.7 & 0. & 0. & & & & & & & & 0.71 & 0. & 0.95 \\
\hline Tekr & & & & 0. & 0.0 & 0.1 & 0.1 & 4. & 1. & 0.1 & 0.0 & 0.4 & & 0.8 & & & 0.0 & $\frac{4}{4}$ & & 0.24 \\
\hline Teknaf-1 & 2 & 86.71 & .07 & 0.12 & 0.89 & 0.21 & 0.18 & 4.23 & 0.25 & .07 & 0.05 & .05 & 02 & 0.05 & 0.05 & 0.02 & 0.07 & 0.07 & 6.14 & 0.75 \\
\hline Teknaf-11 & 20.68 & 79.32 & 0.78 & 3.11 & 0.65 & 3.11 & 0.78 & 3.78 & 1.56 & 0.21 & 0.78 & 0.34 & 0.78 & 1.56 & 0.78 & 0.78 & 0.14 & 0.11 & 0.67 & 0.76 \\
\hline
\end{tabular}

\subsubsection{Moheshkhali}

In Moheshkhali region, heavy mineral content ranges from 7.76 to $18.42 \%$ (Table 5). In Moheshkhali-1 and Moheshkhali-2, heavy minerals concentration shows more enriched than other areas of this region. Hornblende, Zircon, Ilmenite, Magnetite, Garnet are found abundantly.

Table 5: The weight percentage (\%) of light \& heavy minerals at Moheshkhali region.

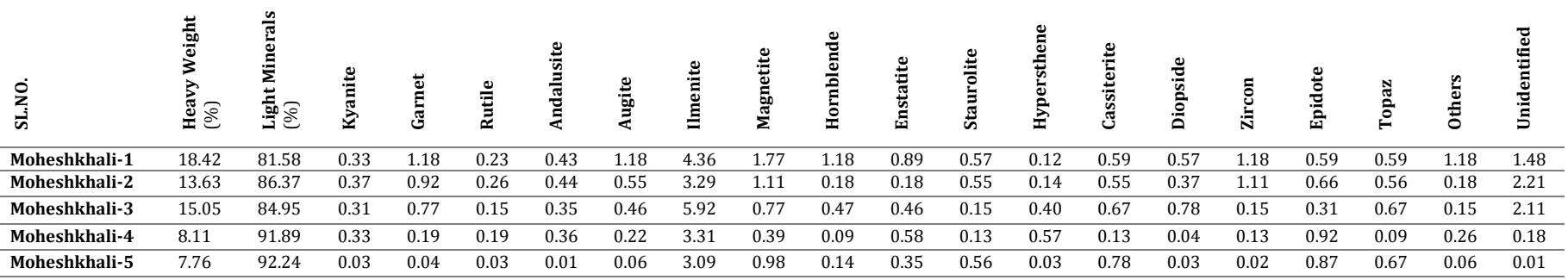

The identification and concentration of heavy minerals showing that North Moheshkhali and some areas of Teknaf sea beach contains more heavy minerals consecutively (max. 18.42\%) and (max. 20.68\%). The most abundant heavy minerals found in the study area are Ilmenite (max. 6.11\%), Magnetite (max. 2.61\%), and Zircon (max. 1.22\%), Garnet (max. named as Zircon, Rutile, Ilmenite, Garnet and Magnetite in his study [3].
$3.11 \%$ ), Augite (max. 1.18\%), Hornblende (max. 3.22\%), Rutile (max. $0.98 \%$ ) (Table 5). However, percentage of heavy mineral assemblages ensure that it is an economically important resource and feasible for exploitation. A researcher also found that there are five major minerals 
Heavy minerals are concentrated in some specific areas mainly in Chorpara (Teknaf-11) beach, Numberi (Teknaf-7) beach, Jahajchora (teknaf-1) beach and Raja-chorav (Teknaf-5) beach in Teknaf upazila containing $20.68 \%, 20.15 \%, 14.21 \%$ and $16.72 \%$ heavy minerals respectively. Imam
Del (Inani-5) and Royal tulip resort (Inani-3) area in Ukhia Upazila contains $19.34 \%$ and $19.71 \%$ heavy minerals respectively. Coastal areas near Himchari region contain $22.33 \%$ heavy minera
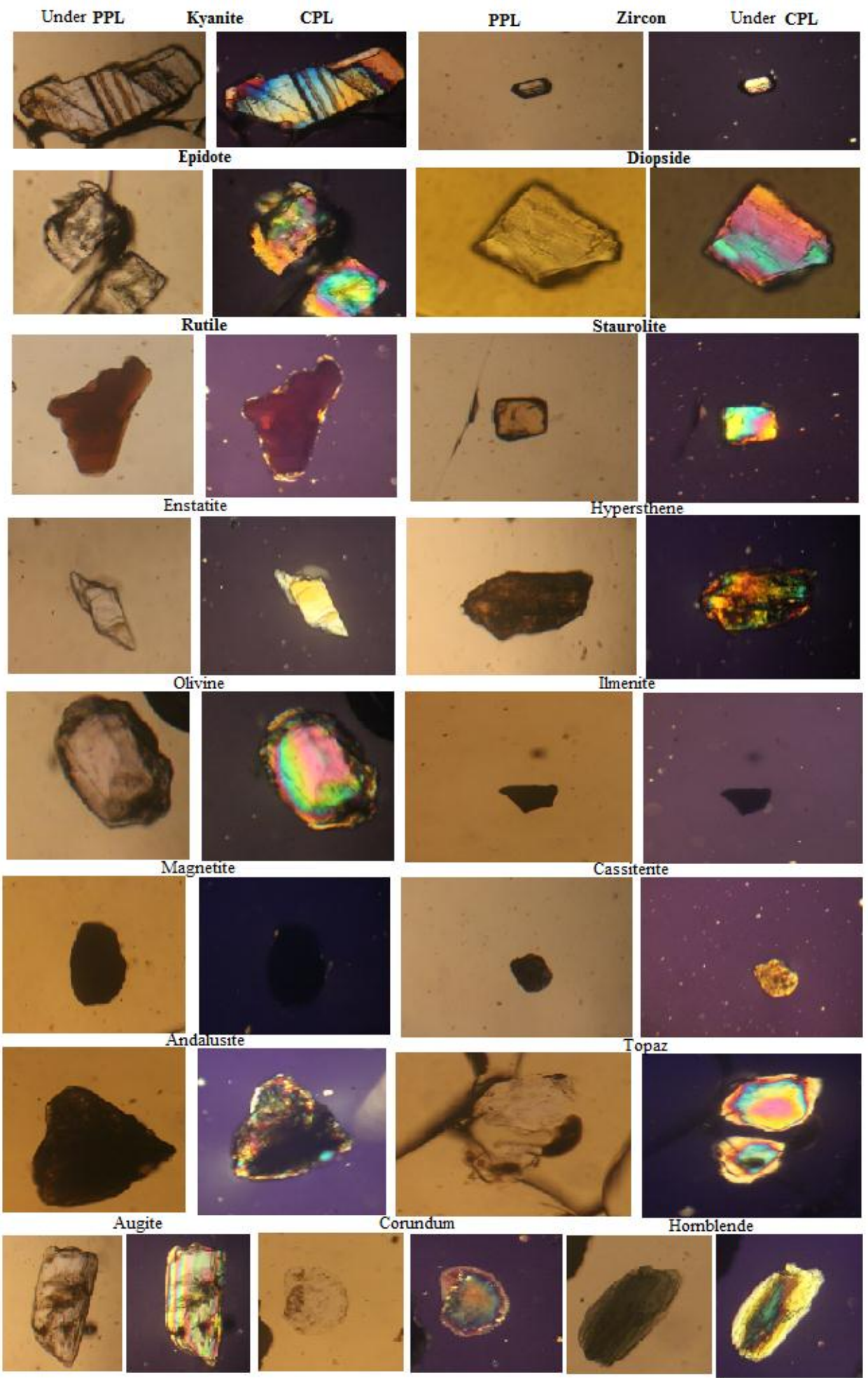

Figure 9: Some identified Heavy minerals under microscope both in Plane and cross polarized light.

\subsection{Result of Remote Sensing Verification}

For satellite image verification, the Lansat-8 OLI image was analyzed. The Analysis confirms that the major heavy mineral deposits are in the sandy long beach of Cox's bazar, Moheshkhali Island, Kutubdia Island, Inani beach, Himchari beach and also the beautiful sandy beach of Teknaf which validate the result obtained from laboratory analysis (Figure 10). The 30 samples analyzed in this study were collected from these major deposit's areas mainly from the Moheshkhali, Inanni, Himchari, long sandy beach of Cox's bazaar and Teknaf.

Result from the image analysis in ENVI shows that the heavy minerals are mostly found in Moheshkhali, Kutubdia, the entire sandy beach area of
Cox's Bazar district (Cox's bazaar- Teknaf) and the region between Myanmar and Bangladesh near the Naf River and in Teknaf region. The distribution of ilmenite and magnetite are higher in coastal areas of Bangladesh [38]. The most important minerals which are identified from the research, are Zircon, Garnet, Ilmenite, Augite and Magnetite are also matched with the result of satellite image analysis (Figure 11). The result from the remote sensing study only showing the relative predicted gross distribution of heavy minerals along the eastern coastal belt of Bangladesh. In some places, results can not be correlated with the finding from field and laboratory analysis due to the coarser resolution of the satellite images. 


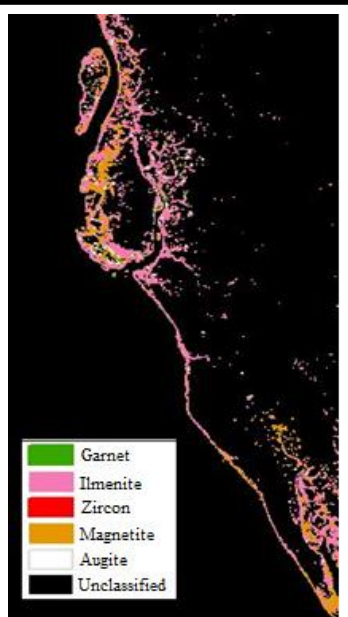

Figure 10: Distribution of heavy minerals along the eastern coastal margin of Bangladesh.
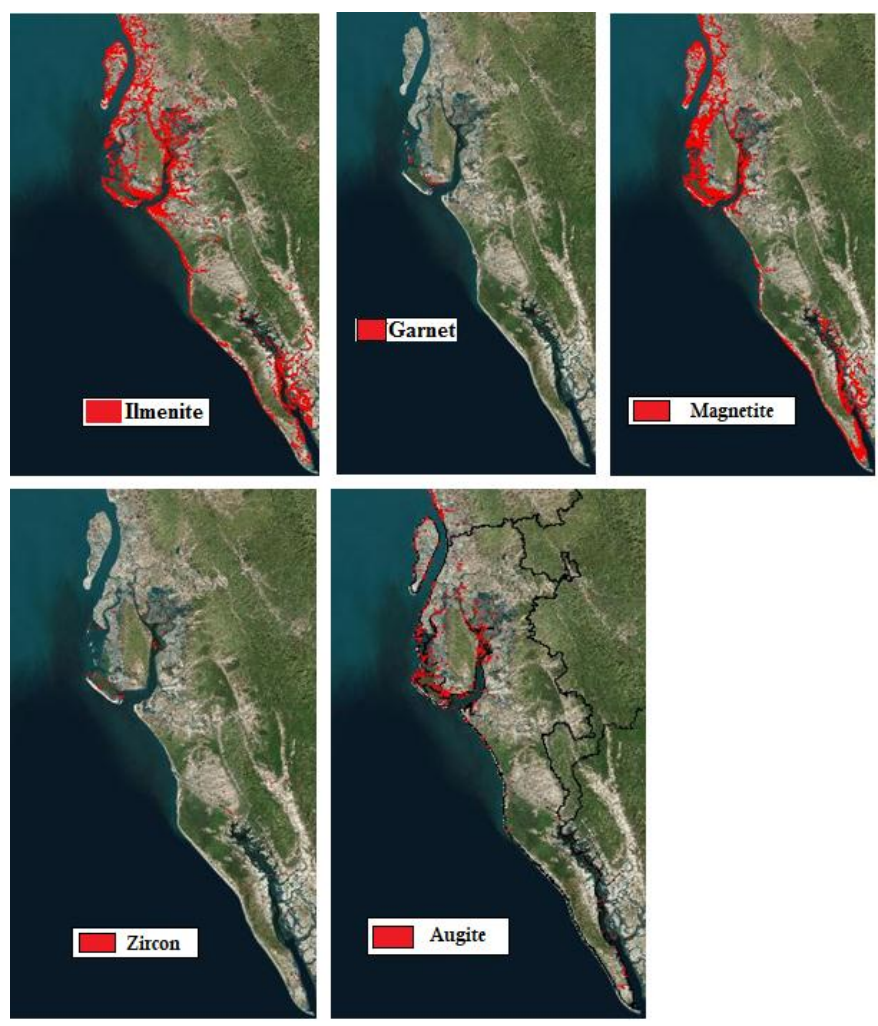

Figure 11: Showing image-based concentration of heavy minerals in the study area. From top (Ilmenite, Garnet, Magnetite, Zircon and Augite) to bottom.

\section{CONCLUSION}

The coastal belt of Bangladesh is very potential for heavy mineral exploitation that would contribute to the economy of Bangladesh. There are many valuable minerals found in the study area such as Zircon, Ilmenite, Augite, Rutile, Magnetite and Garnet. The Teknaf sea beach, Kolatoli and Moheshkhali are comparatively more resourceful in heavy minerals. In this study, heavy minerals mapping from satellite images has given a gross idea of specific mineral concentration in different parts of the area. However, heavy mineral concentration and distribution in the study area was verified with the satellite data and analyzed results are somewhat similar to the findings from geospatial analysis.

\section{ACKNOWLEDGEMENT}

The authors are thankful to the anonymous reviewers for valuable comments and suggestions. The authors wish to express sincere thanks to the Department of Geology, and Oceanography, University of Dhaka, for providing all necessary support to conduct the study.

\section{REFERENCES}

[1] Force, E.R. 1991. Geology of titanium-mineral deposits. Geological Society of America, Special Paper, 259, 112.
[2] Martin, W.R.B., Long, A.M. 1960. Heavy mineral content and radioactivity counts of beach sands west of Oreti river mouth to Blue Cliffs, Southland, New Zealand. New Zealand journal of geology and geophysics, $3(3), 400-409$.

[3] Miah, M.I. 2013. A Study on Heavy Minerals Reserve and Separation Processes from Raw Beach Sands along the Coastal Belt of Bangladesh. International Conference on Mechanical, Industrial and Materials Engineering 2013 (ICMIME2013)1-3 November, 2013, RUET, Rajshahi, Bangladesh.

[4] Ghaznavi, A.A., Quasim, M.A., Singh, P.K., Khan, Z., Albaroot, M., Ahmad, A.H.M. 2017. Significance of heavy minerals as gemstones. National conference on Diamond and other gemstones, 26-27.

[5] Mange, M.A., Wright, D.T. (Eds.). 2007. Heavy minerals in use (Vol. 58). Elsevier

[6] Kabir, M.Z., Deeba, F., Rajib, M. 2006. Optical and mineralogical characteristics of some major beach placer minerals of Bangladesh; Technical report, BSMEC/TR-1/2006, February'06, Beach Sand Minerals Exploitation Center, Bangladesh Atomic Energy Commission, Cox's Bazar, Bangladesh.

[7] Mitra, S., Ahmed, S.S., Moon, H.S. 1992. Mineralogy and chemistry of the opaques of Cox's Bazar (Bangladesh) beach sands and the oxygen fugacity of their provenance. Sediment Geol., 77, 235-247.

[8] Rajib, M., Kabir, M.Z., Deeba, F., Zaman, M.M., Rana, S.M. 2007. Distribution of five major heavy minerals along the recent beach areas of Bangladesh. Bangladesh J. Noami., 24 (1), Pp. 1-P-9.

[9] Bari, Z., Rajib, M., Ameen, S.M.M. 2011. Heavy mineral assemblages of the beach sands of Kuakata, southern Bangladesh. Jahangirnagar University Journal of Science, 34, 143-158.

[10] Rahman, M.A., Biswas, P.K., Zaman, M.N., Miah, M.Y., Hossain, T., Imamul Huq, S.M. 2012. Characterisation of the sand of Brahmaputra river of Bangladesh. Bangladesh Journal of Scientific and Industrial Research, $47,167-172$.

[11] Zaman, M.N., Rahman, M.A., Biswas, P.K. 2012. Sands of the Brahmaputra river basin Bangladesh. Saarbrucken, Germany: Lap LAMBERT Academic Publishing, AV Akademikerverlag GmbH \& Co. KG, Pp.12.

[12] Mange, M.A., Maurer, H.F.W. 1992. Heavy minerals in colour. London: Chapman and Hall; Pp. 147.

[13] Morton, A.C., Hallsworth, C.R. 1999. Processes controlling the composition of heavy mineral assemblages in sandstones. Sediment Geol., 124, 3-29.

[14] Komar, P.D., Wang, C. 1984. Processes of selective grain transport and the formation of placers on beaches. The Journal of Geology, 92 (6), 637 655 .

[15] Li, M.Z., Komar, P.D. 1992. Longshore grain sorting and beach placer formation adjacent to the Columbia River. Journal of Sedimentary Research, 62 (3), 429-441.

[16] Slingerland, R., Smith, N.D. 1986. Occurrence and formation of waterlaid placers. Annual Review of Earth and Planetary Sciences, 14 (1), 113 147.

[17] Peterson, C.D., Komar, P.D., Scheidegger, K.F. 1986. Distribution geometry, and origin of heavy mineral placer deposits on Oregon beaches. Journal of Sedimentary Research, 56 (1), 67-77.

[18] Jasy, J.B., Rahman, M.J.J., Yeasmin, R. 2010. Sand petrology of the exposed bar deposits of the Brahmaputra-Jamuna River, Bangladesh: implications for provenance. Bangladesh Geoscience Journal, 16, 1-22.

[19] Rahman, M.A., Pownceby, M.I., Haque, N., Bruckard, W.J., Zaman, M.N. 2014. Characterisation of titanium-rich heavy mineral concentrates from the Brahmaputra River basin, Bangladesh. Transactions of The Institution of Mining and Metallurgy B, 123, 222-233.

[20] Singh, S.K., France-Lanord, C. 2002. Tracing the distribution of erosion in the Brahmaputra watershed from isotopic compositions of stream sediments. Earth and Planetary Science Letters, 202, 645-662. 
[21] Datta, D.K., Subramanian, V. 1997. Texture and mineralogy of sediments from the Ganges-Brahmaputra-Meghna river system in the Bengal Basin, Bangladesh and their environmental implications. Environmental Geology, 30, 181-188.

[22] Rahman, M.A., Biswas, P.K., Zaman, M.N. 2014. River sands of Bangladesh. Saarbrucken, Germany: Lap Lambert Academic Publishing, AV Akademikerverlag GmbH \& Co, KG; p. 1-73.

[23] Khan, R., Rouf, M.A., Das, S., Tamim, U., Naher, K., Podder, J., Hossain, S.M. 2017. Spatial and multi-layered assessment of heavy metals in the sand of Cox's-Bazar beach of Bangladesh. Regional studies in marine science, 16, 171-180.

[24] Zaman, M.M., Rajib, M., Kabir, M.Z., Deeba, F., Rana, S.M., Hossain, S.M., Rasul, M.G. 2016. Presence of uranium and thorium in zircon assemblages separated from beach sands of Cox's Bazar, Bangladesh. J. Sci. Technol. Environ. Inform., 3 (01), 161-169.

[25] Panday, V.C. 2004. Environment, Security and Tourism Development in South Asia: Tourism development in South Asia. Environment, Security and Tourism Development in South Asia. 3. New Delhi: Gyan Publishing House. Pp. 100-101. ISBN 978-81-8205-139-3.

[26] Rajib, M., Kabir, M.Z., Deeba, F., Zaman, M.M., Rana, S.M. 2007. Distribution of five major heavy minerals along the recent beach areas of Bangladesh. Bangladesh Journal of NOAMI, 24 (1), 1-9.

[27] Gabr, S., Ghulam, A., Kusky, T. 2010. Detecting areas of high-potential gold mineralization using ASTER data. Ore Geology Reviews, 38 (1-2), 5969.

[28] Collins, W., Chang, S.H., Raines, G.L., Canney, F., Ashley, R. 1983. Airborne biogeophysical mapping of hidden mineral deposits. Economic Geology, 78 (4), 737-749.

[29] Wagle, B.G., Gujar, A.R., Mislankar, P.G. 1989. Impact of Coastal Features on Beach Placers: A Case Study Using Remote Sensing Data. In Offshore Technology Conference. Offshore Technology Conference.
[30] Chandrasekar, N., Cherian, A., Paul, D.K., Rajamanickam, G.V., Loveson, V.J. 2005. Geospatial application in the study of beach placer along the coast of Gulf of Mannar, India. Geocarto International, 20 (2), 69-74.

[31] Alam, M.S., Huq, N.E., Rashid, M.S. 1999. Morphology and sediments of the Cox's Bazar coastal plain, south-east Bangladesh. Journal of coastal Research, 902-908.

[32] Ingram, R. L. (1971). Sieve analysis. Procedures in sedimentary petrology, 49-67.

[33] Galehouse, J.S. 1969. Counting grain mounts; number percentage vs. number frequency. Journal of Sedimentary Research, 39 (2), 812-815.

[34] Boardman, J.W., Kruse, F.A., Green, R.O. 1995. Mapping target signatures via partial unmixing of AVIRIS data. In Summaries of the 5th Annual JPL Airborne Geoscience Workshop, January 1995, Pasadena, CA (Pasadena: Jet Propulsion Laboratory), pp. 23-26.

[35] Boardman, J.W. 1993. Automating spectral unmixing of AVIRIS data using convex geometry concepts.

[36] Markham, B.L., Barker, J.L. 1986. Landsat MSS and TM postcalibration dynamic ranges, exoatmospheric reflectances and at-satellite temperatures, EOSAT Landsat Technical Notes No. 1. Lanham, Md.

[37] Van der Meer, F.D., de Jong, S.J. 2003. Spectral mapping methods: many problems, some solutions. In Proceedings of the 3rd EARSeL workshop on imaging spectroscopy, Herrsching, Germany, 13-16 May 2003/ed. by M. Habermeyer, A. Mülle and S. Holzwarth. EARSeL. Pp. 146162 EARSeL.

[38] Deeba, F., Rajib, M., Zaman, M.M. 2009. Difference in Grain size distribution among heavy minerals of cox's bazaar, Barchara, Patuartek and teknaf fore dune depositangladesh. Bangladesh Journal of NOAMI, 24 (1), 1-9

[39] Islam, M.A. 1997. Areal variation of monazite, zircon, magnetite and ilmenite in Cox's Bazar, Bangladesh. J Indian Assoc Sedimentologists., 16, 243-247. 